\title{
Genome-wide association of changes in swine feeding behaviour due to heat stress
}

\author{
Amanda J. Cross ${ }^{1}$, Brittney N. Keel², Tami M. Brown-Brandl², Joseph P. Cassady ${ }^{1}$ and Gary A. Rohrer²*
}

\begin{abstract}
Background: Heat stress has a negative impact on pork production, particularly during the grow-finish phase. As temperature increases, feeding behaviour changes in order for pigs to decrease heat production. The objective of this study was to identify genetic markers associated with changes in feeding behaviour due to heat stress. Feeding data were collected on 1154 grow-finish pigs using an electronic feeding system from July 2011 to March 2016. In this study, days were classified based on the maximum temperature humidity index (THI) during the day as "Normal" $\left(<23.33^{\circ} \mathrm{C}\right)$, "Alert" $\left(23.33^{\circ} \mathrm{C} \leq x<26.11^{\circ} \mathrm{C}\right)$, "Danger" $\left(26.11^{\circ} \mathrm{C} \leq x<28.88^{\circ} \mathrm{C}\right)$, and "Emergency" $\left(\geq 28.88^{\circ} \mathrm{C}\right)$. Six hundred and eighty-one pigs that experienced more than one THI category were genotyped using a variety of SNP platforms, with final genotypes imputed to approximately 60,000 markers.

Results: A genome-wide association study (GWAS) for change in feeding behaviour between each pair of THI categories (six pairs) was conducted. Estimates of heritability for differences in feeding activity between each of the $\mathrm{THI}$ categories were low $(0.02 \pm 0.03)$ to moderate $(0.21 \pm 0.04)$. Sixty-six associations which explained more than $1 \%$ of the genomic variation for a trait were detected across the six GWAS, with the smallest number of associations detected in comparisons with Emergency THI. Gene ontology enrichment analysis showed that biological processes related to immune response and function were over-represented among the genes located in these regions.

Conclusions: Genetic differences exist for changes in feeding behaviour induced by elevated ambient temperatures in grow-finish pigs. Selection for heat-tolerant grow-finish pigs should improve production efficiency during warm months in commercial production. Genetic variation in heat shock, stress response and immune function genes may be responsible for the observed differences in performance during heat stress events.
\end{abstract}

\section{Background}

Heat stress is a major economic concern in the swine industry. In the USA, economic losses due to heat stress are estimated at $\$ 300$ million per year, of which a majority occur during the grow-finish phase [1]. Production losses due to heat stress result from decreased growth of market hogs, reduced feed intake, and mortality [2-4].

Swine feeding behavioural patterns change as temperature increases. Pigs spend less time eating and more time lying down during high temperatures $[5,6]$ and change eating behaviour, mealtime, and meal size $[5,7]$. Nienaber et al. [8] showed that reducing meal size and the

\footnotetext{
*Correspondence: gary.rohrer@ars.usda.gov

2 USDA, ARS, U.S. Meat Animal Research Center, Clay Center, NE 68933, USA

Full list of author information is available at the end of the article
}

number of meals per day can reduce the effects of high temperatures on heat production by decreasing physical and metabolic activity.

Although there have been several advances in production management and barn cooling systems, production efficiency continues to suffer during warm months. Pigs have a thermal comfort zone in which they are most productive, which depends on several factors, including sex, genetics, relative humidity, and velocity of ambient air [9, 10].

Genetic selection for increased growth is associated with a decrease in a pig's ability to handle heat stress [11]. Thus, genetic markers that are associated with heat stress could be used to select for and breed more heat-resilient pigs. The objective of this study was to identify genetic markers associated with changes in feeding behaviour due to heat stress in grow-finish pigs. 


\section{Methods}

All animal protocols conformed to procedures outlined in the Guide for care and use of agricultural animals in agricultural research and teaching [12] and were approved by the USMARC Institutional Animal Care and Use Committee.

\section{Phenotypic data collection}

Phenotypic data were collected on grow-finish pigs $(\mathrm{n}=1648)$, which were reared at the U.S. Meat Animal Research Center from July 2011 to March 2016. Pigs were placed in a barn in grow-finish groups $(n=7)$ of approximately 240 pigs at 8 to 10 weeks of age. Barrows and gilts were mixed and distributed into six pens, with 39 to 40 pigs per pen. Three sire lines, Duroc, Landrace, and Yorkshire, were represented and all dams were from a Landrace-Yorkshire composite population. On average, within a grow-finish group there were 6.2 full-sibs and 25.9 paternal half-sibs represented. Animals were tagged with a low-frequency electronic identification tag upon entry into the grow-finish barn.

Pens were fitted with an electronic feeding system that monitored feeding behaviour, as described by BrownBrandl et al. [13]. Briefly, each pen had one feeder with five slots, allowing up to five animals to eat at any given time. Pigs were provided ad libitum access to a cornsoybean meal diet that was designed to meet or exceed an animal's nutrient requirements. Each feeder slot was fitted with an antenna and a multiplexer. Every $20 \mathrm{~s}$, the device determined which pigs are located at the feeder and then recorded animal number, feeder position and time, which will be referred to as 'RFID pings' hereafter. Data were collected over a 4-month period for each group of pigs.

Each hour, the temperature humidity index (THI) was calculated [14] using outside temperature $\left({ }^{\circ} \mathrm{C}\right)$ and relative humidity $(\mathrm{RH})$ as:

$$
\begin{aligned}
\mathrm{THI}\left({ }^{\circ} \mathrm{C}\right)= & \mathrm{T}\left({ }^{\circ} \mathrm{C}\right)-[0.55-(0.0055 \times \mathrm{RH})] \\
& \times\left[\mathrm{T}\left({ }^{\circ} \mathrm{C}\right)-14.5\right]
\end{aligned}
$$

Days were classified into THI categories based on the maximum THI, as outlined by Brown-Brandl et al. [15]. THI categories included "Normal" $\left(<23.33{ }^{\circ} \mathrm{C}\right)$, "Alert" $\left(23.33{ }^{\circ} \mathrm{C} \leq x<26.11{ }^{\circ} \mathrm{C}\right)$, "Danger" $\left(26.11{ }^{\circ} \mathrm{C} \leq x<28.88^{\circ} \mathrm{C}\right)$, and "Emergency" $\left(\geq 28.88^{\circ} \mathrm{C}\right)$. It should be noted that not all animals experienced every THI category. Only 949 animals experienced a THI greater than Normal. For each animal, the total number of RFID pings was computed for each day, and the average number of RFID pings per day was computed for each THI category. Similarly, the average number of RFID pings per day was computed for each breed by sex combination for each THI category. The difference between an animal's average number of RFID pings in a specific THI category and the corresponding breed-sex mean was computed and standardized to a mean of 0 and a standard deviation of 1 for each THI category. Differences in feeding behaviour between two THI categories (e.g. Alert-Normal) were quantified by calculating the difference in standardized RFID pings between the two categories. Therefore, if an animal experienced all four THI categories during the finishing phase, four standardized THI feeding behaviour values were computed, which reflected how this animal's behaviour deviated from that of a typical animal of this breed type and sex, and six values were computed that indicated how it responded to different temperatures relative to its breed type-sex contemporaries. Not all animals experienced all four THI categories during grow-finish and loss of electronic tags resulted in varying numbers of animals with data for each comparison. It was assumed that animals that reduced their feeding activity more than their breed type-sex contemporaries as the THI category increased, were more affected by heat stress. Phenotypic correlations among the six traits analysed are in Table 1.

\section{Genotypic data}

Tail samples were collected on all pigs and stored at $-20{ }^{\circ} \mathrm{C}$. Genomic DNA was extracted using the WIZARD genomic DNA purification kit according to the manufacturer's protocol (Promega Corp., Madison, WI,

Table 1 Phenotypic correlations among the six temperature-humidity index (THI) category comparisons analysed

\begin{tabular}{llllll}
\hline THI comparison & Normal-Danger & Normal-Emergency & Alert-Danger & Alert-Emergency & Danger-Emergency \\
\hline Normal-Alert & 0.876 & 0.684 & 0.245 & 0.248 & 0.180 \\
Normal-Danger & & 0.832 & 0.682 & 0.506 & 0.326 \\
Normal-Emergency & & 0.675 & 0.874 & 0.795 \\
Alert-Danger & & & 0.704 & 0.420 \\
Alert-Emergency & & & & 0.939 \\
\hline
\end{tabular}

Normal $\left(x<23.33^{\circ} \mathrm{C}\right)$, Alert $\left(23.33^{\circ} \mathrm{C} \leq x<26.11^{\circ} \mathrm{C}\right)$, Danger $\left(26.11^{\circ} \mathrm{C} \leq x<28.88^{\circ} \mathrm{C}\right)$, and Emergency $\left(x \geq 28.88^{\circ} \mathrm{C}\right)$ 
USA). Genotyping was conducted using three platforms: the NeoGen Porcine GGPHD chip (GeneSeek, Lansing, USA), the Illumina Porcine SNP60 V2 chip (Illumina, Inc., San Diego, USA), and the NeoGen GGP-Porcine chip (GeneSeek, Lansing, USA). Quality control involved filtering out genotypes that had a minor allele frequency lower than $5 \%$ and that did not have a unique map position in the Sscrofa10.2 genome assembly [16]. After quality control, 58,096 single nucleotide polymorphisms (SNPs) from the GGPHD chip, 38,598 SNPs from the Porcine SNP60 V2 chip, and 6882 SNPs from the GGPPorcine chip were retained for use in subsequent analyses. In total, 1118 pigs were genotyped using the GGPHD chip, two pigs were genotyped using the SNP60 V2 chip, and 34 pigs were genotyped using the GGP-Porcine chip. Genotypes for animals genotyped on the Porcine SNP60 V2 chip and GGP-Porcine chip were imputed to the NeoGen Porcine GGPHD chip (number of SNPs $=58,096$ ) by pedigree imputation using FImpute v2.2 [17].

\section{Genome-wide association study (GWAS)}

Each of the six traits (difference between the standardized feeding behaviour of two THI categories) was analysed using a mixed linear model with sex, sire breed, and contemporary group as fixed effects. Contemporary group was the combined effect of farrowing group and pen. Two farrowing groups (year-week of birth) were represented in each grow-finish group and the barn contained six pens. Although phenotypes were deviations from the animal's sex and breed of sire means, breed of sire and sex were included as fixed effects to account for population stratification that may be present in the genotypic data. Genomic regions associated with each trait were identified and quantified using a Bayes-C variable selection method and GenSel software [18] based on the following modified statistical model [18]:

$$
\mathbf{y}=\mathbf{X} \boldsymbol{\beta}+\mathbf{Z u}+\mathbf{e}
$$

where $\mathbf{y}$ is a vector of trait phenotypes (differences in feeding behavior between two THI categories), $\mathbf{X}$ is an incidence matrix of fixed effects $(\boldsymbol{\beta}), \mathbf{Z}$ is a matrix of SNP genotypes with non-zero effects (proportion determined as $1-\pi)$ that were fitted as random effects (u) distributed $\mathrm{N}\left(0, \sigma_{u}^{2}\right)$, and $\mathbf{e}$ is a vector of random residual effects assumed to be normally distributed $\mathrm{N}\left(0, \sigma_{\mathbf{e}}^{2}\right)$.

Priors for genetic and residual variances and the prior proportion of SNPs that are assumed to have no effect on the trait within an iteration of the Monte Carlo Markov chain (MCMC) ( $\pi$ ) for each trait were obtained by running Bayes-C $\pi$ using GenSel [18] with the same model as described above. Priors used for Bayes-C $\pi$ analyses were the same for all THI category comparisons and were $0.98,0.10$ and 0.10 for $\pi$, genetic variance and residual variance, respectively. These analyses were run for a minimum of 8100 iterations, with the first 100 discarded as burn-in. Plots of $\pi$ over iterations were evaluated to determine if additional iterations were necessary to obtain a converged estimate. Resulting values for $\pi$ used in Bayes- $C$ analyses are in Table 2.

For the Bayes-C analyses, a chain of 41,000 iterations was used, with the first 1000 cycles discarded as burnin. Effects were sampled every 40 iterations to obtain a posterior distribution for the genetic variance. Genomic regions associated with each trait were identified using $1-\mathrm{Mb}$ genome windows following Wolc et al. [19]. The standard deviation of marker-based estimates of heritability was calculated as the standard deviation of the heritability estimates of the last 100 samples.

\section{Functions of genes in significant genomic regions}

Genes located in 1-Mb windows explaining more than $1.0 \%$ of the genomic variance were obtained using the NCBI annotation of Sscrofa10.2 (Release 104). Two gene lists were analysed. The first contained genes located in all $1-\mathrm{Mb}$ windows that were detected in the six traits. The second list only included genes located in $1-\mathrm{Mb}$ windows that explained more than $3.0 \%$ of the genomic variance for at least one trait. For the latter list, if two adjacent windows exceeded $3.0 \%$ of the genomic variance, then only the $1-\mathrm{Mb}$ region with the greatest estimated effect was included in the analysis.

The PANTHER classification system (version 12.0; http://www.pantherdb.org/) [20] was used to determine the functions of genes in these lists. Enrichment analysis of gene function was performed using PANTHER's implementation of the binomial test of overrepresentation [20], which determines whether the list of genes contains more genes involved in a particular pathway or function than would be expected at random at a Bonferroni corrected $p$ value less than 0.05 . Significance of gene ontology (GO) terms was assessed using the default

Table 2 Posterior estimates of $\pi$ values obtained from Bayes- $C \pi$ analyses and used in Bayes- $C$ analyses for each of the temperature-humidity index (THI) category comparisons

\begin{tabular}{ll}
\hline THI category comparison $^{\mathbf{a}}$ & $\boldsymbol{\pi}$ \\
\hline Normal-Alert & 0.999893 \\
Normal-Danger & 0.999815 \\
Normal-Emergency & 0.999906 \\
Alert-Danger & 0.999954 \\
Alert-Emergency & 0.999947 \\
Danger-Emergency & 0.999943
\end{tabular}

a Normal $\left(x<23.33^{\circ} \mathrm{C}\right)$, Alert $\left(23.33^{\circ} \mathrm{C} \leq x<26.11^{\circ} \mathrm{C}\right)$, Danger $\left(26.11^{\circ} \mathrm{C} \leq x<28.88^{\circ} \mathrm{C}\right)$, and Emergency $\left(x \geq 28.88^{\circ} \mathrm{C}\right)$ 
Ensembl Sus scrofa GO annotation as background for the enrichment analysis.

\section{Results}

Feeding behaviour patterns by breed and sex

Of the 1648 grow-finish pigs (727 barrows and 921 gilts) analyzed in this study, 309 were Duroc sired, 786 were Landrace sired, and 553 were Yorkshire sired. In all three sire breeds, feeding activity of barrows, as determined by the average number of RFID pings per day, exceeded that of gilts for all THI categories (Table 3). Yorkshire and Duroc sired pigs had greater feeding activity than
Landrace sired pigs across all THI categories (Table 3). For Yorkshire and Duroc sired pigs, feeding activity increased as THI increased, while the opposite trend was observed for Landrace sired pigs.

\section{GWAS}

Estimates of heritability from the Bayes-C analyses of GenSel for each THI category comparison are in Table 4 and details for each $1-\mathrm{Mb}$ window that explained more than $1 \%$ of the genomic variance are in Table 5 . Changes in behaviour between Normal and Alert THI categories showed a modest heritability of $0.14( \pm 0.04)$, with more

Table 3 Average number of RFID pings per day (mean \pm standard error) by sire breed and sire breed-sex for each temperature-humidity index (THI) category

\begin{tabular}{|c|c|c|c|c|c|}
\hline Breed & Sex & Normal $x<23.33^{\circ} \mathrm{C}$ & Alert $23.33 \leq x<26.11^{\circ} \mathrm{C}$ & Danger $26.11 \leq x<28.88^{\circ} \mathrm{C}$ & Emergency $x \geq 28.88^{\circ} \mathrm{C}$ \\
\hline \multicolumn{6}{|l|}{ Duroc } \\
\hline & All & $153.4 \pm 0.5$ & $168.9 \pm 0.9$ & $172.7 \pm 1.1$ & $182.6 \pm 3.0$ \\
\hline & Number & 309 & 156 & 155 & 152 \\
\hline & Barrow & $154.8 \pm 0.7$ & $179.0 \pm 1.4$ & $183.5 \pm 1.7$ & $194.3 \pm 4.4$ \\
\hline & Number & 155 & 78 & 78 & 75 \\
\hline & Gilt & $152.0 \pm 0.6$ & $159.1 \pm 1.2$ & $162.1 \pm 1.4$ & $171.1 \pm 4.0$ \\
\hline & Number & 154 & 78 & 77 & 77 \\
\hline \multicolumn{6}{|c|}{ Yorkshire } \\
\hline & All & $140.9 \pm 0.4$ & $145.3 \pm 0.7$ & $150.0 \pm 0.9$ & $157.8 \pm 3.1$ \\
\hline & Number & 553 & 397 & 387 & 256 \\
\hline & Barrow & $156.5 \pm 0.7$ & $160.5 \pm 1.3$ & $170.7 \pm 1.6$ & $188.4 \pm 4.7$ \\
\hline & Number & 214 & 138 & 137 & 84 \\
\hline & Gilt & $130.9 \pm 0.5$ & $135.5 \pm 0.8$ & $137.5 \pm 1.0$ & $137.2 \pm 3.6$ \\
\hline & Number & 339 & 259 & 250 & 172 \\
\hline \multicolumn{6}{|c|}{ Landrace } \\
\hline & All & $134.3 \pm 0.3$ & $122.5 \pm 0.6$ & $108.5 \pm 0.7$ & $65.8 \pm 1.0$ \\
\hline & Number & 786 & 392 & 396 & 390 \\
\hline & Barrow & $140.3 \pm 0.4$ & $131.7 \pm 0.9$ & $118.0 \pm 1.1$ & $71.2 \pm 1.7$ \\
\hline & Number & 358 & 160 & 161 & 159 \\
\hline & Gilt & $129.3 \pm 0.3$ & $115.6 \pm 0.7$ & $101.7 \pm 0.8$ & $62.4 \pm 1.1$ \\
\hline & Number & 428 & 232 & 235 & 231 \\
\hline
\end{tabular}

Table 4 Posterior estimates of heritability for changes in feeding behaviour for each temperature-humidity index (THI) category comparison

\begin{tabular}{llllll}
\hline THI category comparison $^{\mathbf{a}}$ & Number of animals & Range of values & Genomic variance & Residual variance $^{\text {Heritability (SD) }}$ \\
\hline Normal-Alert & 681 & -2.07 to 1.85 & 0.0249 & 0.1577 & $0.136(0.044)$ \\
Normal-Danger & 681 & -2.91 to 2.90 & 0.0602 & 0.2326 & $0.205(0.044)$ \\
Normal-Emergency & 561 & -3.84 to 2.42 & 0.0338 & 0.4028 & $0.077(0.045)$ \\
Alert-Danger & 681 & -1.94 to 2.48 & 0.0050 & 0.0700 & $0.070(0.031)$ \\
Alert-Emergency & 561 & -3.12 to 1.74 & 0.0085 & 0.2303 & $0.036(0.028)$ \\
Danger-Emergency & 561 & -2.72 to 1.19 & 0.0034 & 0.1708 & $0.020(0.026)$ \\
\hline
\end{tabular}

${ }^{\text {a Normal }}\left(x<23.33^{\circ} \mathrm{C}\right)$, Alert $\left(23.33^{\circ} \mathrm{C} \leq x<26.11^{\circ} \mathrm{C}\right)$, Danger $\left(26.11^{\circ} \mathrm{C} \leq x<28.88^{\circ} \mathrm{C}\right)$, and Emergency $\left(x \geq 28.88^{\circ} \mathrm{C}\right)$

b $S D$ standard deviation of the last 100 samplings of the GenSel BayesC analysis 
Table 5 One-Mb windows that explained more than $1 \%$ of the genetic variance for each temperature-humidity index (THI) category comparisons

\begin{tabular}{|c|c|c|c|c|}
\hline THI category comparison ${ }^{a}$ & Chromosome & Position $^{\mathbf{b}}$ (Mb) & $\%$ of genetic variance explained & Number of SNPs \\
\hline \multicolumn{5}{|l|}{ Normal-Alert } \\
\hline & 5 & 68 & 11.9 & 26 \\
\hline & 10 & 44 & 6.2 & 24 \\
\hline & 5 & 108 & 5.6 & 28 \\
\hline & 7 & 53 & 4.8 & 28 \\
\hline & 17 & 2 & 4.8 & 32 \\
\hline & 5 & 107 & 4.5 & 31 \\
\hline & 13 & 85 & 3.1 & 7 \\
\hline & 6 & 15 & 2.8 & 39 \\
\hline & 13 & 17 & 2.8 & 30 \\
\hline & 17 & 3 & 2.6 & 29 \\
\hline & 5 & 109 & 1.8 & 30 \\
\hline & 13 & 16 & 1.8 & 27 \\
\hline & $x$ & 3 & 1.3 & 63 \\
\hline & 13 & 84 & 1.2 & 14 \\
\hline & 7 & 44 & 1.2 & 22 \\
\hline & 5 & 106 & 1.1 & 23 \\
\hline & 15 & 140 & 1.0 & 60 \\
\hline \multicolumn{5}{|l|}{ Normal-Danger } \\
\hline & 7 & 53 & 13.2 & 28 \\
\hline & 10 & 44 & 12.7 & 24 \\
\hline & 1 & 228 & 2.6 & 13 \\
\hline & 1 & 22 & 2.6 & 29 \\
\hline & 1 & 224 & 1.8 & 12 \\
\hline & 5 & 109 & 1.8 & 30 \\
\hline & 13 & 77 & 1.5 & 13 \\
\hline & 6 & 15 & 1.5 & 39 \\
\hline & 7 & 134 & 1.2 & 32 \\
\hline & 5 & 61 & 1.2 & 21 \\
\hline & 7 & 45 & 1.0 & 26 \\
\hline & 7 & 52 & 1.0 & 28 \\
\hline & 6 & 77 & 1.0 & 21 \\
\hline \multicolumn{5}{|l|}{ Normal-Emergency } \\
\hline & 14 & 11 & 8.3 & 42 \\
\hline & 12 & 12 & 5.2 & 35 \\
\hline & 13 & 17 & 2.7 & 30 \\
\hline & 17 & 61 & 2.5 & 50 \\
\hline & 12 & 13 & 2.0 & 39 \\
\hline & $x$ & 3 & 1.8 & \\
\hline & 14 & 13 & 1.8 & 27 \\
\hline & $x$ & 2 & 1.4 & 44 \\
\hline & 2 & 10 & 1.3 & 38 \\
\hline & 5 & 109 & 1.2 & 30 \\
\hline & 18 & 39 & 1.1 & 15 \\
\hline & 13 & 203 & 1.1 & 54 \\
\hline & 10 & 32 & 1.1 & 20 \\
\hline \multicolumn{5}{|l|}{ Alert-Danger } \\
\hline & 1 & 228 & 19.0 & 13 \\
\hline
\end{tabular}


Table 5 continued

\begin{tabular}{|c|c|c|c|c|}
\hline THI category comparison ${ }^{a}$ & Chromosome & Position $^{b}$ (Mb) & $\%$ of genetic variance explained & Number of SNPs \\
\hline & 1 & 226 & 14.3 & 13 \\
\hline & 7 & 53 & 10.2 & 28 \\
\hline & 7 & 52 & 6.2 & 28 \\
\hline & 7 & 134 & 5.0 & 32 \\
\hline & 1 & 227 & 4.4 & 10 \\
\hline & 1 & 224 & 3.1 & 12 \\
\hline & 17 & 22 & 2.3 & 20 \\
\hline & 15 & 30 & 2.1 & 20 \\
\hline & 1 & 283 & 1.5 & 29 \\
\hline & 1 & 223 & 1.4 & 7 \\
\hline & 12 & 12 & 1.4 & 35 \\
\hline & 17 & 4 & 1.0 & 32 \\
\hline \multicolumn{5}{|l|}{ Alert-Emergency } \\
\hline & 14 & 11 & 9.8 & 42 \\
\hline & 14 & 13 & 7.5 & 27 \\
\hline & 1 & 15 & 1.5 & 49 \\
\hline & 12 & 12 & 1.4 & 35 \\
\hline & 14 & 10 & 1.4 & 41 \\
\hline & 15 & 30 & 1.4 & 20 \\
\hline \multicolumn{5}{|l|}{ Danger-Emergency } \\
\hline & 14 & 11 & 4.2 & 42 \\
\hline & 1 & 15 & 1.4 & 49 \\
\hline & 15 & 117 & 1.1 & 15 \\
\hline & 4 & 77 & 1.0 & 28 \\
\hline
\end{tabular}

${ }^{\text {a Normal }}\left(x<23.33^{\circ} \mathrm{C}\right)$, Alert $\left(23.33^{\circ} \mathrm{C} \leq x<26.11^{\circ} \mathrm{C}\right)$, Danger $\left(26.11^{\circ} \mathrm{C} \leq x<28.88^{\circ} \mathrm{C}\right)$, and Emergency $\left(x \geq 28.88^{\circ} \mathrm{C}\right)$

${ }^{b}$ Positions are based on build 10.2 of the swine genome

than $58 \%$ of the genomic variance explained by 17 regions on nine chromosomes. Five regions on Sus scrofa (SSC) chromosome 5 accounted for $24.9 \%$ of genomic variance and SSC13 had four regions that accounted for $8.9 \%$ of the genomic variance. SSC7 and 17 each had two regions that jointly accounted for 6.0 and $7.4 \%$ of the genomic variance, respectively.

Feeding behaviour changes between Normal and Danger THI had the highest estimate of heritability $(0.21 \pm 0.04)$. Over $40 \%$ of the genomic variance was explained by 13 regions on six chromosomes. Four regions on SSC7 jointly accounted for $16.5 \%$ of the genomic variance, while SSC1 had three regions that jointly accounted for $7.1 \%$ of the genomic variance. The estimate of heritability for the Normal-Emergency comparison was considerably lower $(0.08 \pm 0.04)$, with approximately 30\% of genomic variance explained by 13 regions on nine chromosomes. Regions on SSC14 and 12 accounted for the highest percentage of genomic variance (10.1 and $7.3 \%$, respectively).

The estimate of heritability for changes in feeding behaviour between the Alert and Danger categories was similar to that for the Normal-Emergency categories $(0.07 \pm 0.03)$ and $72 \%$ of the genomic variance was explained by regions on five chromosomes. SSC1 had six regions that jointly explained $43.8 \%$ of the genomic variance and SSC7 had three regions that jointly explained $21.5 \%$ of the genomic variance. The estimate of heritability for the Alert-Emergency THI comparison was $0.04 \pm 0.03$ and $23 \%$ of the genomic variance was explained by six regions on four chromosomes. SSC14 had three regions that jointly accounted for $18.7 \%$ of the genomic variance. Almost $8 \%$ of the genomic variance was explained by four regions on separate chromosomes for the Danger-Emergency THI comparison. SSC14 explained the largest proportion of genomic variance (4.2\%). The estimate of heritability for this comparison $(0.02 \pm 0.03)$ was the lowest of the six THI comparisons.

\section{Functions of genes in significant regions}

The PANTHER classification system was used to analyse over-representation of GO terms for the list of genes that were located in significant genomic regions for all six traits, as well as for a shorter list of genes from regions 
that explained more than $3.0 \%$ of the genomic variance. Several significant biological process and molecular function GO terms were over-represented in the full list of genes (Table 6). The most significant molecular functions were "Type I interferon receptor binding" and "Cytokine activity". Most of the 39 over-represented biological process terms were related to immune function, both innate and acquired. The most significant biological process identified was "Positive regulation of peptidyl-serine phosphorylation of STAT protein". The signal transducer and activator of transcription (STAT) protein family regulates both type I and type II interferon receptors, immune function and cell proliferation. PANTHER analysis of genes located in regions associated with more than $3.0 \%$ of the genomic variance identified only two significantly over-represented molecular function terms (Table 7), "Glutathione transferase activity" and "Transferase activity, transferring alkyl or aryl (other than methyl) groups".

\section{Discussion}

Environmental temperature affects feeding behaviour of pigs. In this study, THI was computed using outdoor temperature, but ideally, barn temperatures should be used. Although barn temperatures were collected using thermometers located at each end of the barn, for some groups of pigs there were numerous missing data points due to thermometer failure and other technical issues. Thus, THI from an on-site weather station was found to be a good predictor of barn temperature (adjusted $\mathrm{R}^{2}=0.85$; Fig. 1).

In this study, barrows from all three sire breeds had higher average daily RFID pings than gilts for each THI category. This is consistent with Brown-Brandl et al. [21], who reported that barrows spent more time at feeders than gilts. However, in a different study, Hyun et al. [22] reported no difference in time spent at feeders between sexes. In the study of Hyun et al. [22], the electronic feeding system allowed only one pig to eat at a time, while Brown-Brandl et al. [21] used an electronic feeding system like the one used here, consisting of one feeder with five feeding spaces. Current production systems use multi-space feeders since they are cost-effective and reduce negative social interactions during feeding. An interesting observation in the current study was that the difference in feeding activity between barrows and gilts increased with increasing temperatures for all sire breed by THI categories except Landrace sired pigs in the Emergency category. Thus, the observed difference in feeding activity between barrows and gilts may be due to competition for space or differences in how each sex handles heat stress.
We found that the impact of heat stress on feeding behaviour differs between breeds. Feeding activity of Duroc and Yorkshire sired pigs increased as THI increased, while that of Landrace sired pigs decreased as THI increased. Several approaches have been used to determine a pig's ability to handle stressful situations. To test how a pig copes with a perceived stressful situation, the back test has been used, in which piglets are placed on their backs and time until first struggle or time spent struggling is recorded [23-26]. Time until first struggle is greater for animals that are calmer and that are capable of handling stressful situations better. Rohrer et al. [26] showed that time until first struggle during the back test is positively genetically correlated with number of meals per day and negatively genetically correlated with average meal length. As THI increased, Landrace sired pigs spent less time at the feeder, which suggests that the Landrace sired pigs were less able to handle stressful situations, heat stress in particular, or have a lower thermal comfort zone than Duroc and Yorkshire sired pigs. Hence, differences in heat tolerance can be observed through changes in feeding activity in grow-finish pigs when exposed to increased temperatures.

Several regions were identified in multiple THI category comparisons. One interesting comparison is how animals cope with the most extreme heat, i.e. Emergency THI. These comparisons had low estimates of heritability and typically detected few $1-\mathrm{Mb}$ regions, which could reflect that all animals were considerably stressed during Emergency THI regardless of their genetic background. It should be noted that fewer animals experienced Emergency THI, so these analyses had fewer observations and a reduced power to detect associations. There were three regions (defined as chromosome_position in $\mathrm{Mb}$ ) that were the same (SSC1_15, SSC12_12, and SSC14_11) for the traits including Emergency THI. Similar results should be expected as phenotypic correlations among these traits were relatively high, ranging from 0.80 to 0.94 (Table 1). The SSC14_11 region explained a large portion of the genomic variance in each of the analyses: 8.3, 9.8, and $4.2 \%$ for the comparison of the Emergency THI category to the Normal, Alert, and Danger THI categories, respectively. This region contains the DPYSL2 gene, which is involved in the release of neural peptides from sensory neurons when stimulated [27]. A second possible candidate is the ADRA1A gene, which encodes an adrenergic receptor associated with response to stress hormones such as adrenaline and epinephrine [28]. The SSC12_12 region contains two genes that are associated with blood flow (GNA13 and AMZ2), which may be interesting candidates for study. Once nerves detect an increase in heat, a signal is sent to the hypothalamus that causes warmth-sensitive neurons to trigger a heat-loss 
Table 6 List of ontology terms that were significantly over- and underrepresented in the set of genes located in 1-Mb windows that were identified for at least one temperature-humidity index category comparison

\begin{tabular}{|c|c|c|c|c|c|}
\hline \multirow[t]{2}{*}{ Ontology term } & \multicolumn{5}{|l|}{ Gene set } \\
\hline & $\begin{array}{l}\text { Annotated genes }{ }^{a} \\
(n=21,324)\end{array}$ & Genes $^{b}(n=254)$ & $\begin{array}{l}\text { Number of genes } \\
\text { expected }\end{array}$ & $\begin{array}{l}\text { Over }(+) \text { or under }(-) \\
\text { represented }\end{array}$ & $p$ value \\
\hline \multicolumn{6}{|l|}{ Biological process } \\
\hline $\begin{array}{l}\text { Positive regulation of pep- } \\
\text { tidyl-serine phosphoryla- } \\
\text { tion of STAT protein }\end{array}$ & 36 & 10 & 0.43 & + & $2.37 E-07$ \\
\hline $\begin{array}{l}\text { Natural killer cell activation } \\
\text { involved in immune } \\
\text { response }\end{array}$ & 37 & 10 & 0.45 & + & $3.08 \mathrm{E}-07$ \\
\hline $\begin{array}{l}\text { Regulation of peptidyl-ser- } \\
\text { ine phosphorylation of } \\
\text { STAT protein perception }\end{array}$ & 38 & 10 & 0.46 & + & $3.98 \mathrm{E}-07$ \\
\hline B cell proliferation & 48 & 10 & 0.58 & + & $3.70 E-06$ \\
\hline Natural killer cell activation & 50 & 10 & 0.60 & + & $5.45 \mathrm{E}-06$ \\
\hline $\begin{array}{l}\text { Response to exogenous } \\
\text { dsRNA }\end{array}$ & 51 & 10 & 0.61 & + & $6.58 \mathrm{E}-06$ \\
\hline $\begin{array}{l}\text { T cell activation involved in } \\
\text { immune response }\end{array}$ & 56 & 10 & 0.67 & + & $1.59 E-05$ \\
\hline $\begin{array}{l}\text { Mononuclear cell prolifera- } \\
\text { tion }\end{array}$ & 73 & 11 & 0.88 & + & 1.44E-05 \\
\hline Lymphocyte proliferation & 73 & 11 & 0.88 & + & $1.44 \mathrm{E}-05$ \\
\hline Leukocyte proliferation & 77 & 11 & 0.93 & + & $2.49 \mathrm{E}-05$ \\
\hline Response to dsRNA & 72 & 10 & 0.87 & + & $1.66 \mathrm{E}-04$ \\
\hline $\begin{array}{l}\text { Positive regulation of } \\
\text { peptidyl-serine phos- } \\
\text { phorylation }\end{array}$ & 88 & 11 & 1.06 & + & $9.63 E-05$ \\
\hline Defense response to virus & 110 & 13 & 1.33 & + & $9.08 \mathrm{E}-06$ \\
\hline $\begin{array}{l}\text { Lymphocyte activation } \\
\text { involved in immune } \\
\text { response }\end{array}$ & 88 & 10 & 1.06 & + & $1.04 \mathrm{E}-03$ \\
\hline B cell differentiation & 89 & 10 & 1.07 & + & $1.16 \mathrm{E}-03$ \\
\hline $\begin{array}{l}\text { Regulation of peptidyl- } \\
\text { serine phosphorylation }\end{array}$ & 112 & 12 & 1.35 & + & $1.14 \mathrm{E}-04$ \\
\hline $\begin{array}{l}\text { Humoral immune } \\
\text { response }\end{array}$ & 96 & 10 & 1.16 & + & $2.29 E-03$ \\
\hline $\begin{array}{l}\text { Leukocyte activation } \\
\text { involved in immune } \\
\text { response }\end{array}$ & 111 & 12 & 1.34 & + & $8.36 \mathrm{E}-03$ \\
\hline $\begin{array}{l}\text { Cell activation involved in } \\
\text { immune response }\end{array}$ & 113 & 10 & 1.36 & + & $9.79 E-03$ \\
\hline $\begin{array}{l}\text { Adaptive immune } \\
\text { response }\end{array}$ & 137 & 12 & 1.65 & + & $9.80 E-04$ \\
\hline T cell activation & 161 & 14 & 1.94 & + & $9.81 E-05$ \\
\hline B cell activation & 117 & 10 & 1.41 & + & $1.33 \mathrm{E}-02$ \\
\hline Response to virus & 158 & 13 & 1.90 & + & $6.05 \mathrm{E}-04$ \\
\hline Regulation of STAT cascade & 125 & 10 & 1.51 & + & 2.37E-02 \\
\hline $\begin{array}{l}\text { Regulation of JAK-STAT } \\
\text { cascade }\end{array}$ & 125 & 10 & 1.51 & + & $2.37 \mathrm{E}-02$ \\
\hline Lymphocyte differentiation & 171 & 12 & 2.06 & + & $9.79 \mathrm{E}-03$ \\
\hline Lymphocyte activation & 241 & 15 & 2.90 & + & $2.17 \mathrm{E}-03$ \\
\hline Leukocyte differentiation & 230 & 14 & 2.77 & + & $6.96 \mathrm{E}-03$ \\
\hline Cell proliferation & 322 & 19 & 3.88 & + & $1.33 \mathrm{E}-04$ \\
\hline Immune effector process & 257 & 15 & 3.10 & + & $4.81 \mathrm{E}-03$ \\
\hline
\end{tabular}


Table 6 continued

\begin{tabular}{|c|c|c|c|c|c|}
\hline \multirow[t]{2}{*}{ Ontology term } & \multicolumn{5}{|l|}{ Gene set } \\
\hline & $\begin{array}{l}\text { Annotated genes }{ }^{a} \\
(n=21,324)\end{array}$ & Genes $^{b}(n=254)$ & $\begin{array}{l}\text { Number of genes } \\
\text { expected }\end{array}$ & $\begin{array}{l}\text { Over }(+) \text { or under }(-) \\
\text { represented }\end{array}$ & $p$ value \\
\hline $\begin{array}{l}\text { Response to organic cyclic } \\
\text { compound }\end{array}$ & 377 & 20 & 4.54 & + & $3.13 \mathrm{E}-04$ \\
\hline $\begin{array}{l}\text { Defense response to other } \\
\text { organism }\end{array}$ & 264 & 14 & 3.18 & + & $3.34 \mathrm{E}-02$ \\
\hline Leukocyte activation & 284 & 15 & 3.42 & + & $1.62 \mathrm{E}-02$ \\
\hline Cell activation & 357 & 18 & 4.30 & + & $3.08 \mathrm{E}-03$ \\
\hline $\begin{array}{l}\text { Response to nitrogen } \\
\text { compound }\end{array}$ & 471 & 21 & 5.68 & + & $2.47 \mathrm{E}-03$ \\
\hline $\begin{array}{l}\text { Response to organic } \\
\text { substance }\end{array}$ & 1460 & 43 & 17.60 & + & $3.57 \mathrm{E}-04$ \\
\hline Cell differentiation & 2021 & 49 & 24.36 & + & $1.22 \mathrm{E}-02$ \\
\hline $\begin{array}{l}\text { Cellular developmental } \\
\text { process }\end{array}$ & 2077 & 49 & 25.03 & + & $2.59 \mathrm{E}-02$ \\
\hline Developmental process & 3175 & 67 & 38.27 & + & $1.45 \mathrm{E}-02$ \\
\hline Sensory perception & 1326 & 1 & 15.98 & - & $7.80 \mathrm{E}-03$ \\
\hline \multicolumn{6}{|l|}{ Molecular function } \\
\hline $\begin{array}{l}\text { Type I interferon receptor } \\
\text { binding }\end{array}$ & 32 & 10 & 0.39 & + & $2.61 \mathrm{E}-08$ \\
\hline $\begin{array}{l}\text { Glutathione transferase } \\
\text { activity }\end{array}$ & 27 & 5 & 0.33 & + & $4.88 \mathrm{E}-02$ \\
\hline Cytokine activity & 177 & 17 & 2.13 & + & $2.12 \mathrm{E}-07$ \\
\hline Cytokine receptor binding & 218 & 15 & 2.63 & + & $2.12 \mathrm{E}-04$ \\
\hline Receptor binding & 1030 & 33 & 12.41 & + & $8.36 \mathrm{E}-04$ \\
\hline $\begin{array}{l}\text { G-protein coupled recep- } \\
\text { tor activity }\end{array}$ & 1445 & 3 & 17.42 & - & $4.06 \mathrm{E}-02$ \\
\hline \multicolumn{6}{|l|}{ Cellular component } \\
\hline Cytoplasm & 7080 & 118 & 85.33 & + & $1.70 E-02$ \\
\hline
\end{tabular}

Table 7 List of ontology terms that were significantly over- and underrepresented in the set of genes located in 1-Mb windows that were associated with more than $3 \%$ of genetic variance for at least one temperature-humidity index category comparisons

\begin{tabular}{|c|c|c|c|c|c|}
\hline \multirow[t]{2}{*}{ Ontology term } & \multicolumn{5}{|l|}{ Gene set } \\
\hline & $\begin{array}{l}\text { Annotated genes }{ }^{a} \\
(n=21,324)\end{array}$ & Genes $^{b}(n=44)$ & $\begin{array}{l}\text { Number of genes } \\
\text { expected }\end{array}$ & $\begin{array}{l}\text { Over }(+) \text { or under }(-) \\
\text { represented }\end{array}$ & $p$ value \\
\hline \multicolumn{6}{|l|}{ Biological process } \\
\hline \multicolumn{6}{|l|}{ None } \\
\hline \multicolumn{6}{|l|}{ Molecular function } \\
\hline $\begin{array}{l}\text { Glutathione transferase } \\
\text { activity }\end{array}$ & 27 & 5 & 0.07 & + & 3.35E-05 \\
\hline $\begin{array}{l}\text { Transferase activity, } \\
\text { transferring alkyl or aryl } \\
\text { groups }\end{array}$ & 54 & 5 & 0.15 & + & $1.01 \mathrm{E}-03$ \\
\hline \multicolumn{6}{|l|}{ Cellular component } \\
\hline None & & & & & \\
\hline
\end{tabular}

a Number of genes in the Sus scrofa 10.2 annotation set with given GO term. Total number of annotated genes in the Sus scrofa 10.2 annotation is in parentheses

b Number of genes with given GO term located in genomic regions explaining at least 3\% of genomic variance for one of more THI comparison GWAS. Total number of annotated genes residing in the selected regions is in parentheses 


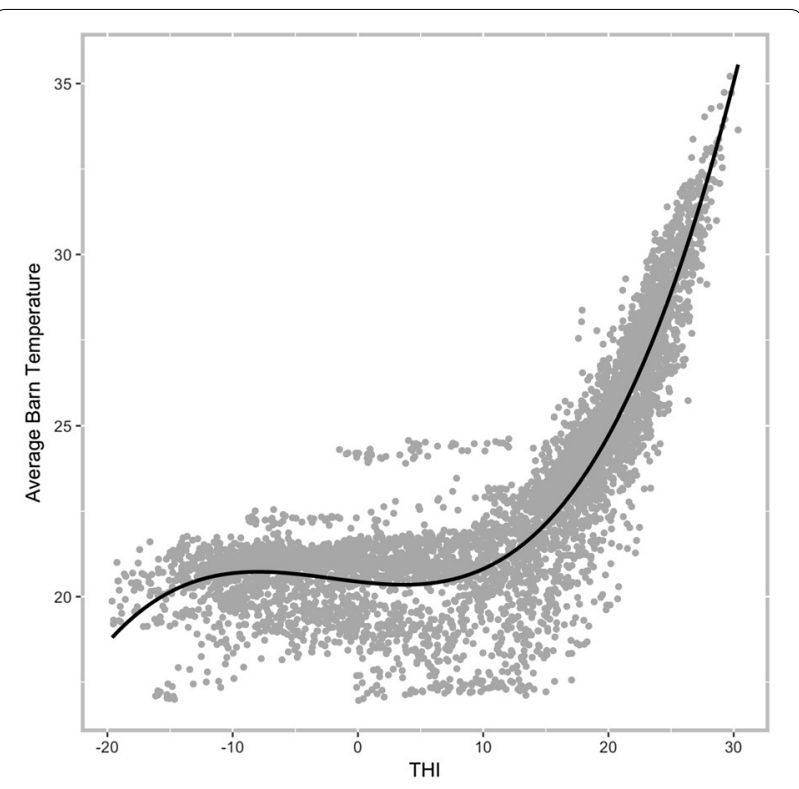

Fig. 1 Temperature-humidity index $\left(\mathrm{THI} ;{ }^{\circ} \mathrm{C}\right)$ versus average barn temperature $\left({ }^{\circ} \mathrm{C}\right)$ using a 3 rd degree polynomial regression across all time periods when both measures were available

reflex by either vasoconstriction or behavioural mechanisms [29]. Moran et al. [30] postulated that one critical component to thermal tolerance is an individual's ability to direct greater blood flow to the skin for heat dissipation. Unlike most other mammals, pigs have a limited capacity to use water evaporation to lose heat [31], so dissipation of heat through skin is critical to their thermal regulation.

A second interesting comparison is how animals change their behaviour when temperatures exceed Normal values. In these comparisons, estimates of heritability were moderate and more regions of interest were detected than in analyses comparing the three levels of heat stress (Alert, Danger and Emergency). Phenotypic correlations among these three traits were also high (range 0.68-0.88; Table 1) but not as high as the correlations with traits associated with Emergency THI. Six similar regions were identified in comparisons to the Normal category (SSC5_109, SSC6_15, SSC7_53, SSC10_44, SSC13_17 and SSCX_3). The SSC 7_53 region was detected in two of the three comparisons to Normal (Normal-Alert, and Normal-Danger) as well as the comparison of Alert-Danger and each association explained a relatively large amount of the genomic variance (4.8, 13.2 and $10.3 \%$, respectively). Evaluation of this region identified a heat shock protein gene (DNAJA4), which is located at $53.2 \mathrm{Mb}$. Heat shock proteins protect cells from stressors [32]. The DNAJA4 gene was shown to be expressed at higher levels after heat stress in chicken testes [33] and in several tissues in heat stressed rats [34] than in unstressed control animals. This region also contains members of the acetylcholine receptor subunit family. Two of these genes, CHRNA3 and CHRNB4, form a complex that activates POMC neurons, which stimulate $M C 4 R$ and regulate eating behaviour [35]. Thus, these three genes (DNAJA4, CHRNA3, and CHRNA5) warrant further investigation.

A potential candidate gene for the SSCX_3 region is NLGN4X, which is expressed in the brain. A mouse model in which this gene is knocked out showed that null mice had deficits in social interactions and communication with other mice [36]. An expanded region on SSC7 between 44 and $45 \mathrm{Mb}$, which was identified in the comparisons of Normal THI with the Alert and Danger categories, contains two heat shock protein genes, HPS $90 A A 1$ and HSP9OAB1, located at $45.1 \mathrm{Mb}$. The HSP90AA1 gene encodes an inducible protein expressed during cellular stress that is more highly expressed in the testes of heat-stressed chickens [33] than in control birds. Polymorphisms in the HSP90AA1 gene have been associated with adaptation to thermal conditions in sheep [37], while polymorphisms in the HSP90AB1 gene have been associated with heat tolerance in cattle [38].

In order to gain a better biological insight into the genetic mechanisms that control heat tolerance in pigs, an enrichment analysis of gene function was performed using PANTHER. The most over-represented biological processes were related to the immune system. Several reports have also associated immune function genes with an animal's response to heat stress. Moran et al. [30] summarized that an animal's heat response cascade included three components beginning with heat shock proteins, followed by expression of interferon-inducible genes and concluding with small non-specific stress responses of specific cell lines. Islam et al. [39] found greater expression of inflammatory cytokines after exposure to heat stress in mice that were intolerant to heat relative to mice that were determined to be heat tolerant. Altered white blood cell counts and antibody production due to heat stress have also been documented [40] in poultry. Therefore, selection of immune function genes residing in the regions identified in this study warrant further investigation.

At the cellular level, heat stress disrupts normal folding of newly synthesized proteins [34], which then are not recognized as a native protein and will be targeted for degradation. The glutathione transferase pathway breaks down molecules, which are recognized as potential toxins or foreign material, and Stallings et al. [34] showed that genes in this pathway are upregulated during heat stress. We observed that the glutathione transferase molecular function was significantly over-represented in regions detected in both PANTHER analyses (Tables 6 and 7) 
confirming the importance of the glutathione transferase pathway as one of an animal's biological mechanisms to cope with elevated temperatures.

\section{Conclusions}

Changes in feeding activity are indicative of response to heat stress in grow-finish pigs. Individual differences in tolerance to heat have been identified in mice [39], man [30], and in pigs (current study) and our results show that thermal tolerance in pigs is heritable. Genes involved in immune response and function were among those overrepresented in the regions associated with changes in feeding activity between different THI categories. Candidate genes identified in this work, including heat shock proteins and stress response, merit further investigation and may facilitate genetic selection for improved growfinish performance during heat stress events. Selection for heat-tolerant grow-finish pigs would increase production efficiency.

\section{Authors' contributions}

GAR and TMBB raised the initial questions, designed the project, and collected data. AJC conducted the analyses and wrote the manuscript. BNK conducted bioinformatics analyses. JPC added valuable suggestions. All authors read and approved the final manuscript.

\section{Author details}

${ }^{1}$ Department of Animal Science, South Dakota State University, Brookings, SD 57007, USA. ${ }^{2}$ USDA, ARS, U.S. Meat Animal Research Center, Clay Center, NE 68933, USA.

\section{Acknowledgements}

The authors would like to thank K. Simmerman for excellent technical assistance and the U.S. Meat Animal Research Center swine caretakers for outstanding husbandry. Mention of trade name, proprietary product, or specified equipment does not constitute a guarantee or warranty by the USDA and does not imply approval to the exclusion of other products that may be suitable. The USDA is an equal opportunity provider and employer.

\section{Competing interests}

The authors declare that they have no competing interests.

\section{Availability of data and materials}

The datasets generated and/or analysed during the current study are available in the AnimalQTLdb repository, www.animalgenome.org.

\section{Ethics approval}

All animal protocols conformed to procedures outlined in Guide for Care and Use of Agricultural Animals in Agricultural Research and Teaching [12] and were approved by the USMARC Institutional Animal Care and Use Committee under the USMARC Swine Standard Operating Procedures Protocol.

\section{Funding}

Funding for this project was supplied by USDA CRIS \#3040-31000-094-00D.

\section{Publisher's Note}

Springer Nature remains neutral with regard to jurisdictional claims in published maps and institutional affiliations.

Received: 31 May 2017 Accepted: 26 February 2018

Published online: 25 March 2018
References

1. St-Pierre NR, Cobanov B, Schnitkey G. Economic losses from heat stress by US livestock industries. J Dairy Sci. 2003;86:E52-77.

2. Nienaber JA, Hahn GL, McDonald TP, Korthals RL. Feeding patterns and swine performance in hot environments. Trans ASAE. 1996;39:195-202.

3. Collin A, Vaz MJ, Le Dividich J. Effect of high temperature on body temperature and hormonal adjustments in piglets. Reprod Nutr Dev. 2002:42:45-53.

4. Gabler NK, Pearce SC. The impact of heat stress on intestinal function and productivity in grow-finish pigs. Anim Prod Sci. 2015;55:1403-10.

5. Hicks TA, McGlone JJ, Whisnant CS, Kattesh HG, Norman RL. Behavioral, endocrine, immune, and performance measures from pigs exposed to acute stress. J Anim Sci. 1998;76:474-83.

6. Brown-Brandl TM, Eigenberg RA, Nienaber JA, Kachman SD. Thermoregulatory profile of a newer genetic line of pigs. Livest Prod Sci. 2001;71:253-60.

7. Collin A, van Milgent J, Le Dividich J. Modeling the effect of high, constant temperature on food intake in young growing pigs. Anim Sci. 2001;72:519-27.

8. Nienaber JA, Hahn GL, Eigenberg RA. Quantifying livestock responses for heat stress management: a review. Int J Biometeorol. 1999;42:183-8.

9. National Research Council US. Subcommittee on environmental stress. Effect of environment on nutrient requirements of domestic animals. Washington: National Academy Press; 1981.

10. Nyachoti CM, Zijlstra RT, de Lange CFM, Patience JF. Voluntary feed intake in growing-finishing pigs: a review of the main determining factors and potential approaches for accurate predictions. Can J Anim Sci. 2004;84:549-66.

11. Renaudeau D, Gourdine JL, St-Pierre NR. A meta-analysis of the effects of high ambient temperature on growth performance of growing-finishing pigs. J Anim Sci. 2011;89:2220-30.

12. Federation of Animal Science Societies (FASS). Guide for the care and use of agricultural animals in research and teaching, vol. 3. Champaign: Federation of Animal Science Societies; 2010.

13. Brown-Brandl TM, Eigenberg RA. Development of a livestock feeding behaviour monitoring system. Trans ASAE. 2011;54:1913-20.

14. National Oceanic and Atmospheric Administration (NOAA). Livestock hot weather stress: Operations manual letter C-31-76. Kansas City: US Department of Commerce, National Weather Service Central Region; 1976.

15. Brown-Brandl TM, Eigenberg RA, Nienaber JA. Benefits of providing shade to feedlot cattle of different breeds. Trans ASAE. 2013;56:1563-70.

16. Groenen MAM, Archibald AL, Uenishi H, Tuggle CK, Takeuchi Y, Rothschild $M F$, et al. Analysis of pig genomes provide insight into porcine demography and evolution. Nature. 2012;491:393-8.

17. Sargolzaei M, Chesnais JP, Schenkel FS. A new approach for efficient genotype imputation using information from relatives. BMC Genomics. 2014;15:478.

18. Fernando R, Garrick DJ. GenSel: user manual for a portfolio of genomic selection related analyses. Ames: Iowa State University; 2008.

19. Wolc A, Arango J, Settar P, Fulton JE, O'Sullivan NP, Preisinger R, et al. Genome-wide association analysis and genetic architecture of egg weight and egg uniformity in layer hens. Anim Genet. 2012;43(Suppl 1):87-96.

20. Mi H, Huang X, Muruganujan A, Tang H, Mills C, Kang D, Thomas PD. PANTHER version 11: expanded annotation data from gene ontology and reactome pathways, and data analysis tool enhancements. Nucleic Acids Res. 2017;45:D183-9.

21. Brown-Brandl TM, Rohrer GA, Eigenberg RA. Analysis of feeding behavior of group housed growing-finishing pigs. Comput Electron Agric. 2013;96:246-52.

22. Hyun Y, Ellis M, McKeith FK, Wilson ER. Feed intake pattern of group housed growing-finishing pigs monitored using a computerized feed intake recording system. J Anim Sci. 1997;75:1443-51.

23. Hessing MJC, Hagelsø AM, van Beek JAM, Wiepkema PR, Schouten WGP, Krukow R. Individual behavioural characteristics in pigs. Appl Anim Behav Sci. 1993;37:285-95.

24. Cassady JP. Evidence of phenotypic relationships among behavioral characteristics of individual pigs and performance. J Anim Sci. 2007:85:218-24.

25. Velie BD, Maltecca C, Cassady JP. Genetic relationships among pig behavior, growth, backfat, and loin muscle area. J Anim Sci. 2009;87:2767-73. 
26. Rohrer GA, Brown-Brandl T, Rempel LA, Schneider JF, Holl J. Genetic analysis of behavior traits in swine production. Livest Sci. 2013;157:28-37.

27. Brittain JM, Duarte DB, Wilson SM, Zhu W, Ballard C, Johnson PL, et al. Suppression of inflammatory and neuropathic pain by uncoupling CRMP-2 from the presynaptic $\mathrm{Ca}(2+)$ channel complex. Nat Med. 2011;17:822-9.

28. Chang DJ, Chang TK, Yamanishi SS, Salazar FHR, Kosaka AH, Khare R, et al. Molecular cloning, genomic characterization and expression of novel human alpha-1A-adrenoceptor isoforms. FEBS Lett. 1998;422:279-83.

29. Caterina MJ. Transient receptor potential ion channels as participants in thermosensation and thermoregulation. Am J Physiol Regul Integr Comp Physiol. 2007;292:R64-76.

30. Moran DS, Eli-Berchoer L, Heled Y, Mendel L, Schocina M, Horowitz M. Heat intolerance: does gene transcription contribute? J Appl Physiol. 2006;100:1370-6.

31. Ingram DL. The effect of humidity on temperature regulation and cutaneous water loss in the young pig. Res Vet Sci. 1965;6:9-17.

32. Basiricò L, Morera P, Primi V, Lactera N, Nardone A, Bernabucci U. Cellular thermotolerance is associated with heat shock protein 70.1 genetic polymorphisms in Holstein lactating cows. Cell Stress Chaperones. 2011;16:441-8.

33. Wang SH, Cheng CY, Tang PC, Chen CF, Chen HH, Lee YP, et al. Differential gene expressions in testes of L2 strain Taiwan country chicken in response to acute heat stress. Theriogenology. 2013;79:374-82.

34. Stallings JD, Ippolito DL, Rakesh V, Baer CE, Dennis WE, Helwig BG, et al. Patterns of gene expression associated with recovery and injury in heatstressed rats. BMC Genomics. 2014;15:1058.
35. Mineur YS, Abizaid A, Rao Y, Salas R, DiLeone RJ, Gundisch D, et al. Nicotine decreases food intake through activation of POMC neurons. Science. 2011;332:1330-2.

36. Jamain S, Radyushkin K, Hammerschmidt K, Granon S, Boretuis S, Varoqueaux $F$, et al. Reduced social interaction and ultrasonic communication in a mouse model of monogenic heritable autism. Proc Nat Acad Sci USA 2008;105:1710-5.

37. Marcos-Carcavilla A, Mutikainen M, González C, Calvo JH, Kantanen J, Sanz A, et al. A SNP in the SP90AA1 gene 5' flanking region is associated with the adaptation to differential thermal conditions in the ovine species. Cell Stress Chaperones. 2010;15:67-81.

38. Charoensook R, Gatphayak K, Sharifi AR, Chaisongkram C, Brenig B, Knorr C. Polymorphisms in the bovine HSP90AB1 gene are associated with heat stress tolerance in Thai indigenous cattle. Trop Anim Health Prod. 2012;44:921-8.

39. Islam A, Deuster PA, Devaney JM, Ghimbovschi S, Chen Y. An exploration of heat tolerance in mice utilizing mRNA and microRNA expression analysis. PLoS One. 2013;8:e72258.

40. Mashaly MM, Hendricks GL 3rd, Kalama MA, Gehad AE, Abbas AO, Patterson $\mathrm{PH}$. Effects of heat stress on production parameters and immune responses of commercial laying hens. Poult Sci. 2004;83:889-94.

\section{Submit your next manuscript to BioMed Central and we will help you at every step:}

- We accept pre-submission inquiries

- Our selector tool helps you to find the most relevant journal

- We provide round the clock customer support

- Convenient online submission

- Thorough peer review

- Inclusion in PubMed and all major indexing services

- Maximum visibility for your research

Submit your manuscript at www.biomedcentral.com/submit 